\title{
Multi-kinase Inhibitor XL092
}

National Cancer Institute

\section{Source}

National Cancer Institute. Multi-kinase Inhibitor XL092. NCI Thesaurus. Code C161598.

An orally bioavailable, receptor tyrosine kinase (RT K) inhibitor with potential antineoplastic activity. Upon oral administration, multi-kinase inhibitor XL092 strongly binds to and inhibits several RT Ks that are often overexpressed in a variety of cancer cell types, including hepatocyte growth factor receptor (proto-oncogene c-Met) and certain vascular endothelial growth factor receptor (VEGFR) subtypes. This may result in an inhibition of both tumor growth and angiogenesis, and eventually lead to tumor regression. 